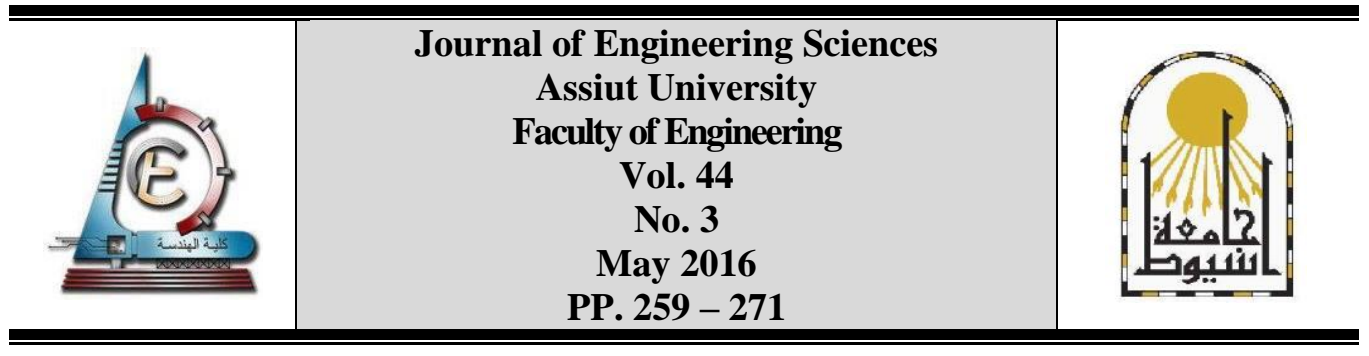

\title{
IMPROVING OF LIGHTWEIGHT SELF- CURING CONCRETE PROPERTIES
}

\author{
Mohammed M. M. Rashwan ${ }^{1}$, Hesham M. A. Diab ${ }^{2}$ and Yahia M. S. Abd El-Fattah *, 3 \\ Civil Eng. Dept., Assuit University, 71516 Assuit.
}

Received 5 April 2016; Accepted 18 May 2016

\begin{abstract}
This study investigates the effect of self-curing agents on the mechanical properties of concrete. The self-curing agent is prewetted lightweight aggregate crushed over burnt clay bricks (COBCB). The COBCB has been used for replacement coarse aggregates in a ratios of $20 \%, 50 \%$ and $100 \%$. The mechanical properties were evaluated while the concrete specimens were subjected to different curing methods; conventional water curing, air curing regime (in the laboratory environment with $25^{\circ} \mathrm{C}$ ) and chemical curing. The results show that, the use of self-curing agents COBCB in concrete with replacement ratio $20 \%$ by volume of coarse aggregates is effectively improved the mechanical properties in all cases of curing.
\end{abstract}

Keywords: Self curing, Lightweight aggregates, mechanical properties.

\section{Introduction}

In practice, the conventional type of curing needs a large amount of water, which is lost due to evaporation and runoff. Internal curing refers to the use of prewetted lightweight aggregate (LWA) to provide sufficient moisture which is required for hydrating of cement paste. In this case, the concrete will achieve excellent properties. Internal curing is done by replacing a percentage of coarse aggregate with LWA such as COBCB. The water in COBCB is typically stored in pores that are larger than those in a hydrating cement paste. As a result, the water moves from the LWA to the surrounding cement particles keeping the small pores saturated until the time when moisture equilibrium is reached between the reservoirs and the surrounding cement paste which reducing dry shrinkage of cement paste. Also, it utilizes cement more efficiently during the hydration process. Furthermore, internal curing improves the workability of the concrete and reduces the cracks due to plastic, drying and thermal shrinkage. Moreover, the concrete strength is increased because the bond between the LWA and the hydrated cement increases due to decrease in the permeability of the concrete.

\section{Literature survey}

Holm.T.A. [1] stated that, shale's, clays, and slates have been expanded in rotary kilns to produce structural grade LWA for use in concrete and masonry units for more than 80 years.

\footnotetext{
* Corresponding author.

E- mail address: yahia_samir91@yahoo.com
} 
Millions of tons of structural grade LWA produced annually are used in structural concrete applications [1]. Khokrin, N.K discussed the unique physical characteristics of rotary kiln expanded slate LWA for producing high performance and high strength lightweight concrete. The compressive strength, elastic modulus, splitting tensile strength, specific creep and other properties of lightweight concrete are significantly affected by the structural properties of the lightweight aggregate used. Concrete production, transportation, pumping and placing are also affected [2]. Hoff. G.C. described the use of saturated LWA as a replacement for a portion of the normal weight aggregate (NWA) in high-strength/high-performance concrete in order to mitigate or eliminate the self-desiccation and autogenous shrinkage that can occur which can further lead to early age cracking and long-term durability problems. The amount of LWA used to achieve beneficial internal curing is a function of the type of LWA, its size and amount, the degree of moisture preconditioning the LWA receives, the amount and type of binder(s) in the mixture, the water-binder ratio at mixing, as well as the amount and duration of external moist curing provided to the concrete element [3]. ArnonBentura et.al. studied the concrete with saturated LWA exhibited no autogenous shrinkage, whereas the normal-weight concrete with the same matrix exhibited large shrinkage. The study shows that; the partial replacement of NWA with $25 \%$ by volume of saturated LWA was very effective in eliminating the autogenous shrinkage and restrained stresses of the normal-weight concrete. It is noted that; the internal supply of water from the saturated LWA to the high-strength cement matrix causes continuous expansion, which may be related to continuous hydration [4]. Ryan Henkensiefkenet. al indicated that, while internal curing may have been originally developed to reduce autogenous shrinkage and mitigate early-age cracking in high performance concrete, its application has far-reaching consequences for the performance of concrete throughout its lifetime. By providing an on-demand source of extra water, internal curing can improve the slump retention, workability and finishability of fresh concrete and reduce deformations and cracking due to plastic, autogenous and drying shrinkage [5]. J. Schlitter noted that, the compressive strength of internally cured mixtures with LWA $11 \%$ to $24 \%$ was reduced in the range of $2 \%$ to $8 \%$ as compared with plain mixtures without LWA. The split tensile capacity of internally cured mixtures using LWA was slightly less than the control mixture, but no general trend could be found. Internally cured mixtures with LWA were up to $13 \%$ softer than the plain mixture [6]. Dayalan J found that, the internally cured concrete resulted in an increment of compressive strength with $20 \%$ higher than plain concrete up to $20 \%$ replacement. The improved hydration also reduces micro cracking as a result of the lower shrinkage tendency of concrete with LWA (Expanded Shale) used for internal curing [7]. Magda I. Mousa showed that, 15\% saturated leca represent the optimum doses as self-curing agents in concrete. This investigation stated that, the indirect tensile strength was in the range of $6.4 \%$ to $8.5 \%$ of the compressive strength. The test results of flexural strength represented $10-14.5 \%$ of the compressive strength [8].

\section{Experimental program}

\subsection{Material properties}

The used materials to conduct this work are:

A. Cement: Ordinary Portland cement CEM I 42.5 was used for all concrete mixes. The properties of the used cement agreed with ECP 203 [9] (Assiut cement) and is listed in Table (1).

B. Coarse Aggregate: Local gravel and crushed over burnt clay bricks (COBCB) were used as coarse aggregate. Fig. (1) shows COBCB aggregate samples. COBCB size was 
Yahia M. S. Abd El-Fattah et al., Improving of lightweight self-curing concrete properties

reduced by using Morse Jaw Crusher its photo shown in Fig. (2).

C. Fine aggregate: Local sand was used as fine aggregate. The used sand is a medium type.

The percentage passing of aggregates given in Table (2). The physical and chemical properties of aggregates are given in Tables ( $3 \& 4)$ respectively.

D. Water: Potable water was used.

Table 1.

Physical properties of the used O.P.C.

\begin{tabular}{|c|c|c|c|}
\hline \multicolumn{2}{|l|}{ Physical test } & $\begin{array}{l}\text { Average } \\
\text { values }\end{array}$ & Specification limits \\
\hline \multicolumn{2}{|c|}{ Water Required for Standard Consistency } & 0.27 & Not exceeded than 0.5 \\
\hline \multicolumn{2}{|c|}{ Initial setting time (minutes) } & 165 & Not less than 45 min. \\
\hline \multicolumn{2}{|c|}{ Final setting time (minutes) } & 370 & Not exceeded than 10 hours \\
\hline \multicolumn{2}{|c|}{ Specific surface area $\left(\mathrm{cm}^{2} / \mathrm{gm}\right)$} & 3320 & Not less than 2500 \\
\hline \multirow{2}{*}{ Compressive strength $\left(\mathrm{kg} / \mathrm{cm}^{2}\right)$} & 3-day & 195 & Not less than 183 \\
\hline & 7-day & 290 & Not less than 275 \\
\hline
\end{tabular}

Table 2.

$\%$ passing of used aggregates.

\begin{tabular}{|c|c|c|c|c|c|c|c|c|c|}
\hline $\begin{array}{c}\text { Sieve size } \\
\text { (mm.) }\end{array}$ & 40 & 20 & 10 & 5 & 2.5 & 1.25 & 0.63 & 0.31 & 0.16 \\
\hline $\begin{array}{c}\text { (\%) of Passing } \\
\text { (sand) }\end{array}$ & 100 & 100 & 100 & 100 & 92 & 76 & 50 & 17 & 0 \\
\hline $\begin{array}{c}\text { (\%) of Passing } \\
\text { (Gravel) }\end{array}$ & 100 & 75 & 25 & 5 & -- & -- & -- & -- & -- \\
\hline $\begin{array}{c}(\%) \text { of Passing } \\
\text { (COBCB) }\end{array}$ & 100 & 94 & 38 & 2 & -- & -- & -- & -- & -- \\
\hline
\end{tabular}

Table 3.

Physical properties of aggregates.

\begin{tabular}{|c|c|c|c|c|}
\hline \multicolumn{2}{|c|}{ Property } & Sand & Gravel & COBCB \\
\hline \multicolumn{2}{|c|}{ Specific gravity } & 2.5 & 2.5 & 1.35 \\
\hline \multirow{2}{*}{ Unite weight $\left(\mathrm{t} / \mathrm{m}^{3}\right)$} & Loose & 1.44 & 1.56 & 0.98 \\
\hline & Compact & 1.6 & 1.67 & 1.03 \\
\hline \multicolumn{2}{|c|}{ Shape Factor } & 1.18 & 1.13 & 1.16 \\
\hline \multicolumn{2}{|c|}{ Maximum nominal size $(\mathrm{mm})$} & --- & 40 & 40 \\
\hline \multicolumn{2}{|c|}{ Fineness modulus } & 2.45 & 7.11 & 7.7 \\
\hline \multicolumn{2}{|c|}{ Specific surface area $\left(\mathrm{cm}^{2} / \mathrm{gm}\right)$} & 56.24 & 2.06 & 2.03 \\
\hline \multicolumn{2}{|c|}{$\%$ Water Absorption (By Weight) } & 1.2 & 0.64 & 13.25 \\
\hline
\end{tabular}

Table 4.

Chemical properties of aggregate

\begin{tabular}{|c|c|c|c|}
\hline Property & Sand & Gravel & COBCB \\
\hline \% of Chloride ions & 0.04 & 0.008 & 0.018 \\
\hline \% of Sulphates ions & 0.129 & 0.012 & 0.04 \\
\hline Power of Hydrogen (PH) & 8.5 & 8 & 10.5 \\
\hline \% of Clay and Other Fine Materials Content & 2.5 & 0.7 & 0.8 \\
\hline
\end{tabular}



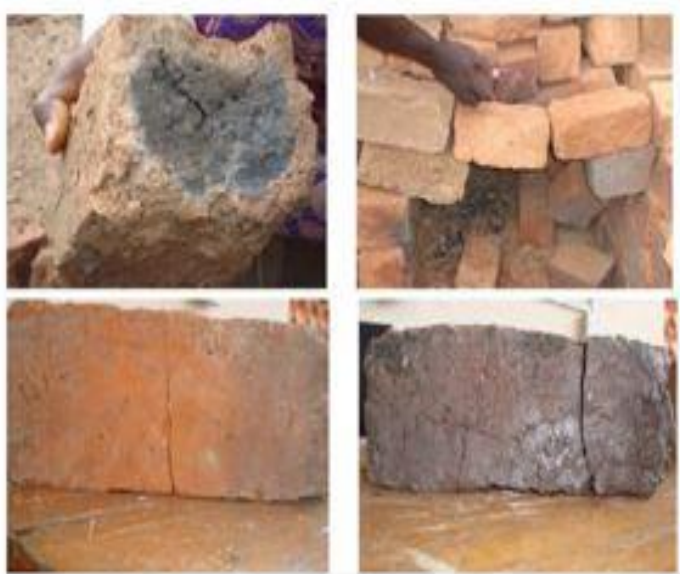

Fig. 1. The used COBCB aggregate samples.

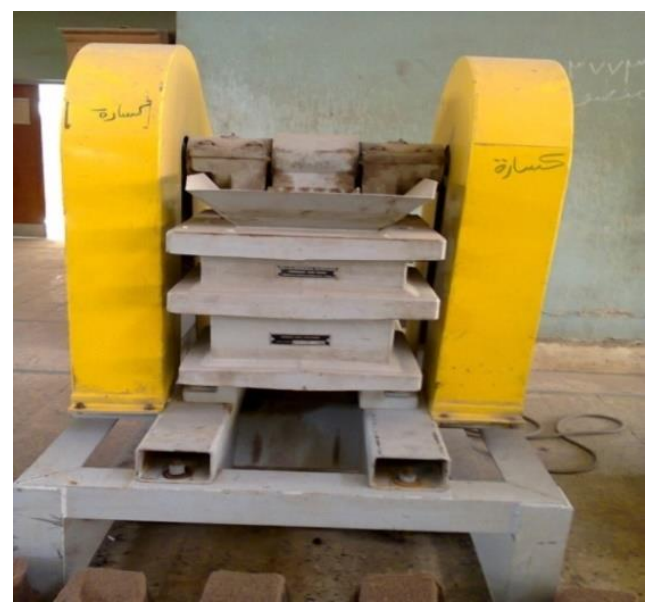

Fig. 2. Morse Jaw Crusher.

\subsection{Proposed mix design}

The concrete mix was designed to produce normal strength concrete having 28-days cubic compressive strength of $250 \mathrm{~kg} / \mathrm{cm}^{2}$. The required free water to cement ratio is 0.48 . COBCB is mixed in proportions of $20 \%, 50 \%$ and $100 \%$ by replacing the coarse aggregates (by volume). In case of neglecting the water absorption of COBCB, the slump was $2 \mathrm{~cm}$. To keep the slump of the concrete mixtures between 7 to $8 \mathrm{~cm}$, COBCB water absorption must be taken into consideration and added to water-cement ratio. The mix proportions are given in the Table (5). Deign Equations used as follows:

- Determination of combined specific surface area.

$$
\mathrm{A}_{\mathrm{CC}}=\left[\frac{\mathrm{B}}{\mathrm{B}+\mathrm{G}}\right] * \mathrm{~A}_{\mathrm{B}}+\left[\frac{\mathrm{G}}{\mathrm{B}+\mathrm{G}}\right] * \mathrm{~A}_{\mathrm{G}}
$$

Where:

- $A_{C C}$ specific surface area of combined coarse aggregate.

- $A_{B} \quad$ specific surface area of COBCB. $\quad-A_{G} \quad$ specific surface area of Gravel.

- Determination of combined specific weight.

$$
\gamma_{C C}=\left[\frac{B}{B+G}\right] * \gamma_{B}+\left[\frac{G}{B+G}\right] * \gamma_{G}
$$

Where:

- $\gamma_{\mathrm{CC}}$ specific weight of combined coarse aggregate.

- $\gamma_{B}$ specific weight of COBCB.

- Determination of water - cement ratio (W/C).

$\mathrm{W} / \mathrm{C}=\frac{\mathrm{A} * \mathrm{Fc} \text { cement }}{\mathrm{Fc} \text { mean }+0.5 * \mathrm{~A} * \mathrm{Fc} \text { cement }}$

Where:

- $\mathrm{F}_{\mathrm{C} \text { Cement }}$ Compressive strength of cement. $-\mathrm{F}_{\mathrm{C} \text { mean }}$ The mean compressive strength.

- A Constant value.

- Determination of materials amount.

- Determination the amount of materials to cast $1 \mathrm{~m}^{3}$. 
Yahia M. S. Abd El-Fattah et al., Improving of lightweight self-curing concrete properties

$$
\frac{c}{\gamma c}+\frac{G}{\gamma g}+\frac{s}{\gamma s}+\frac{W}{\gamma w}=1 m^{3}
$$

Table 5.

Amount of constitute materials for $1 \mathrm{~m}^{3}$ of the used concrete

\begin{tabular}{|c|c|c|c|c|c|c|c|}
\hline \multirow{2}{*}{$\begin{array}{c}\text { Group } \\
\text { No. }\end{array}$} & \multicolumn{7}{|c|}{ Mix component, Kg/m ${ }^{3}$} \\
\cline { 2 - 8 } & Cement & Sand & Gravel & COBCB & Water & W/C & Slump (cm) \\
\hline M0 & 350 & 822 & 1141 & -- & 168 & 0.48 & 7.10 \\
\hline M20 & 350 & 713 & 792 & 198 & $168+26.24^{*}$ & 0.55 & 7.40 \\
\hline M50 & 350 & 650 & 445 & 445 & $168+58.96^{*}$ & 0.65 & 7.80 \\
\hline M100 & 350 & 505 & -- & 700 & $168+92.75^{*}$ & 0.75 & 8.20 \\
\hline
\end{tabular}

* Amount of water absorbed by COBCB.

\subsection{Mixing preparation}

The used LWA should be fully saturated; accordingly, it was submerged in water for 24 hours right before casting. A stationary mixer was used to blend the raw materials together. As the dry raw materials are mixed well, water was added to the mixer. The constituents were mixed homogeneously. The test specimens were cast in cast-iron molds. The inside of the molds were coated with oil to facilitate the removal of specimens.

\subsection{Preparation after mixing}

After the molds are filled with concrete, it is compacted and the surface is leveled. The specimens were kept in the laboratory conditions for 24 hours. Then, they were demolded and divided into three different cases of curing as follows:

i) Conventional curing (CC): specimens were submerged in water (as a reference).

ii) No curing (NC): air curing regime (in the laboratory environment with $25^{\circ} \mathrm{C}$ )

iii) Chemical curing (Ch.C): specimens were painted by keroseel.

\subsection{Fresh concrete properties}

Slump test was carried out according to Egyptian Standard Specification No. 1658/1988, Part 1, and the Egyptian Code of Practice (203).

\subsection{Hardened concrete properties}

\subsubsection{Compressive strength test}

This test is carried out on $15 \times 15 \times 15 \mathrm{~cm}$ size cubes. A 150 Ton capacity Compression Testing Machine (CTM) is used to conduct the test.

\subsubsection{Indirect tensile strength test}

The Splitting tensile strength of concrete cylinder was determined. The test was carried out on a cylinder of $15 \mathrm{~cm}$ diameter and a $30 \mathrm{~cm}$ height 3 .

\subsubsection{Flexural strength test}

The test is carried out on $10 \times 10 \times 50 \mathrm{~cm}$ size prisms.

The above tests were measured the average of three specimens at 3, 7, 28 and 56 days. 


\section{Results and discussions}

\subsection{Fresh concrete properties}

\subsubsection{Workability test}

The workability of concrete was tested by slump cone test for all concrete mixes. The results are given in table (4).

\section{Table 6.}

Slump Cone Test Values

\begin{tabular}{|c|c|c|c|c|}
\hline Mix design & M0 & M20 & M50 & M100 \\
\hline Slump value $(\mathrm{cm})$ & 7.10 & 7.40 & 7.80 & 8.20 \\
\hline
\end{tabular}

The above results are consistent with those noted by previous researchers. For instance, Dayalan $\mathbf{J}$ [7] reported that, the slump of mixtures is increased as the replacement ratio increased compared with conventional concrete without COBCB. This is due to the additional water in $\mathrm{COBCB}$.

\subsection{Hardened concrete properties}

- The effect of lightweight aggregate replacement ratio on the hardened concrete properties $(0 \% \mathrm{COBCB}$ as reference):

A. Unit Weight: Fig. (3) shows the relationship between the replacement percentage and the unit weight of concrete. It is apparent that, increasing replacement proportions results in a reduction in the unit weight of the concrete. The results also show that, the specimens with $100 \%$ replacement ratio exhibit the highest percentage of reduction in the unit weight. For concrete without $\mathrm{COBCB}$, the unit weight was $2.55 \mathrm{t} / \mathrm{m}^{3}$ but when $100 \%$ (COBCB) replacement ratio the unit weight was $1.98 \mathrm{t} / \mathrm{m}^{3}$ this means that the reduction in unit weight is $22.35 \%$ compared with concrete without $\mathrm{COBCB}$. This result is almost certainly due to the higher amount of cement mortar attached to the $100 \%$ COBCB replacement concrete compared with other samples. Increment of air content can be attributed to the higher porosity of the lightweight aggregate. The net effect is that concretes mixed with lightweight aggregate have lower masses due to the higher air void content.

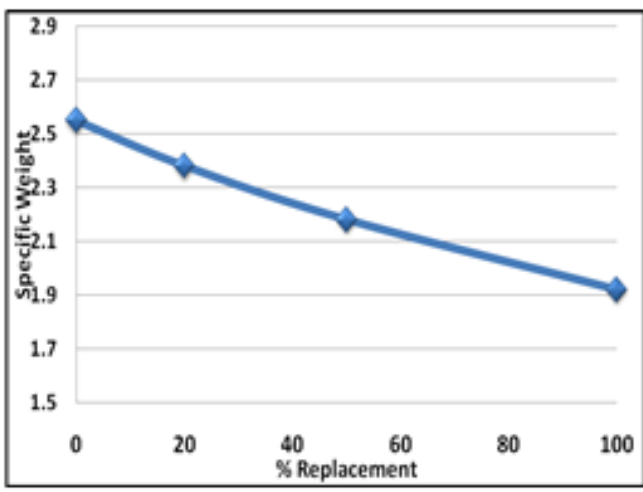

Fig. 3. Effect of \% (COBCB) on Specific Weight

B. Compressive Strength: Fig. (4) shows the compressive strength of all studied concrete mixes either conventional curing, no-curing or chemical curing concretes, which 
Yahia M. S. Abd El-Fattah et al., Improving of lightweight self-curing concrete properties

increase gradually with time in different rates. At 28 days concrete with $20 \%$ COBCB gives higher compressive strength by about $1.7 \%$ for the conventional curing and nocuring concrete and by about $2 \%$ for the chemical curing concrete compared with the conventional concrete $0 \% \mathrm{COBCB}$. This increment may be attributed to the continuation of the hydration process as a result of providing the cement paste by store water in the saturated $\mathrm{COBCB}$ particles. This causes greater bond force between the cement paste and aggregate. After 20\% COBCB replacement compressive strength begins to decrease tile the concretes containing 100\% COBCB give lower compressive strength compared with conventional concrete for all types of curing. At 28 days concrete with $100 \%$ COBCB give lower compressive strength by about $8.1 \%$ for conventional curing concrete, by about $6.8 \%$ for no-curing concrete and by about $7.7 \%$ for chemical curing concrete compared with conventional concrete $0 \% \mathrm{COBCB}$.

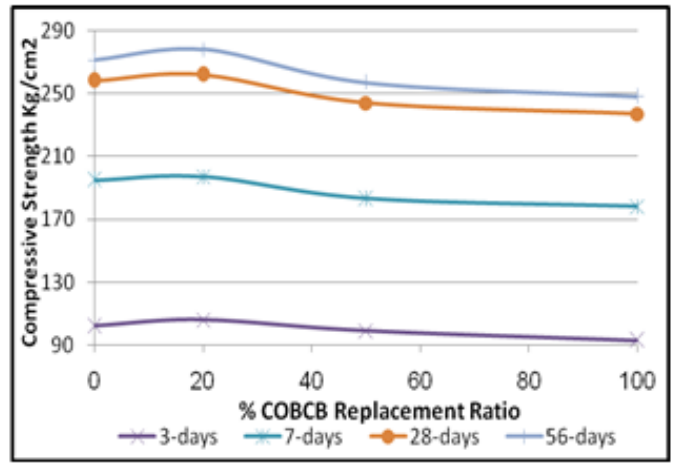

Conventional Curing

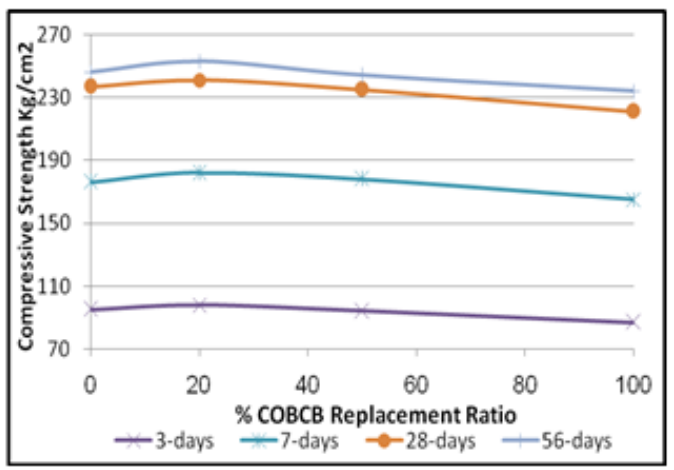

No-Curing

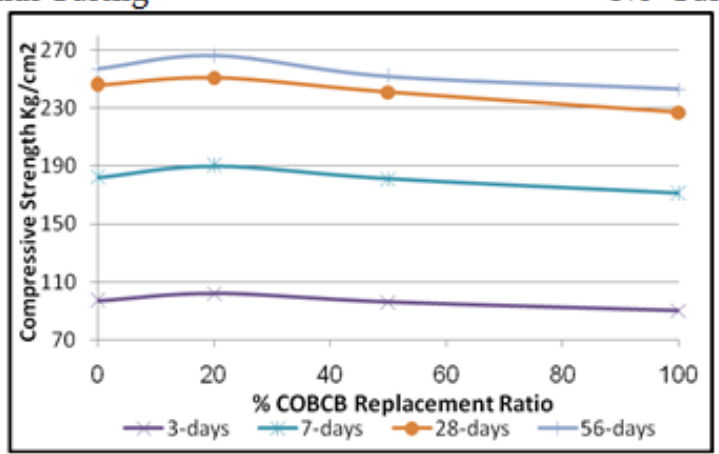

Chemical Curing

Fig. 4. Effect of \% (COBCB) on compressive strength.

C. Indirect Tensile Strength: Fig. (5) shows the indirect tensile strength of all the concretes studied either self-curing, chemical curing or conventional curing concretes. The indirect tensile strength of concretes with or without COBCB (reference concrete) is increased with time. at 28 days a $20 \% \mathrm{COBCB}$ gave the highest increase in tensile strength by about $4.3 \%$ for conventional curing concrete, by about $2.1 \%$ for self-curing concrete and by about $3 \%$ for chemical curing concrete when compared with conventional concrete without COBCB.

D. Flexural strength: Fig. (6) shows that, the flexural strength for all the concrete mixes studied either self-curing, chemical curing or conventional concretes, which increase gradually with time in different rates. The concrete containing 20\% (COBCB) gave a higher 28 days strength by about $5 \%$ for all cases of curing relative to conventional concrete $(0.0 \% \mathrm{COBCB})$. 
JES, Assiut University, Faculty of Engineering, Vol. 44, No. 3, May 2016, pp. 259 - 271
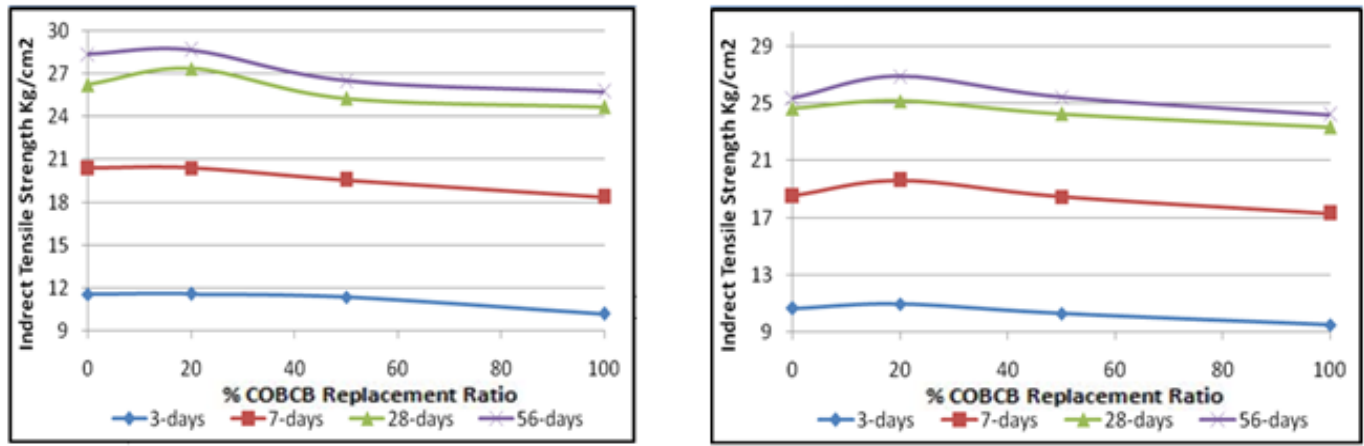

Conventional Curing No-Curing

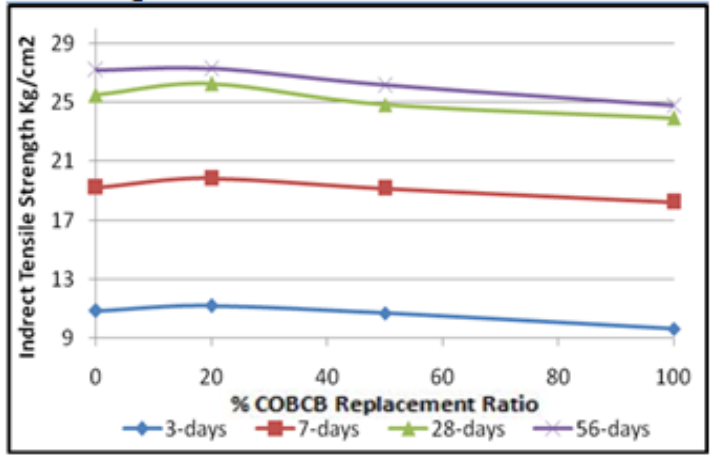

Chemical Curing

Fig. 5. Effect of \% (COBCB) on indirect tensile strength.

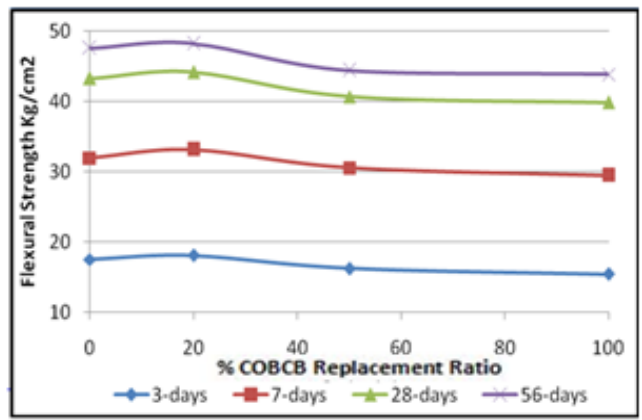

Conventional Curing

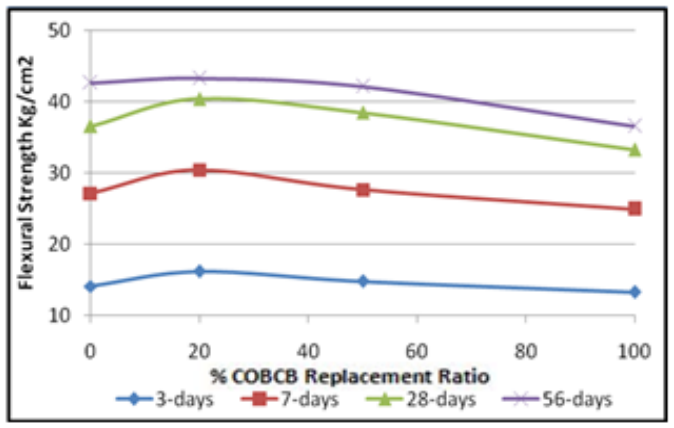

No-Curing

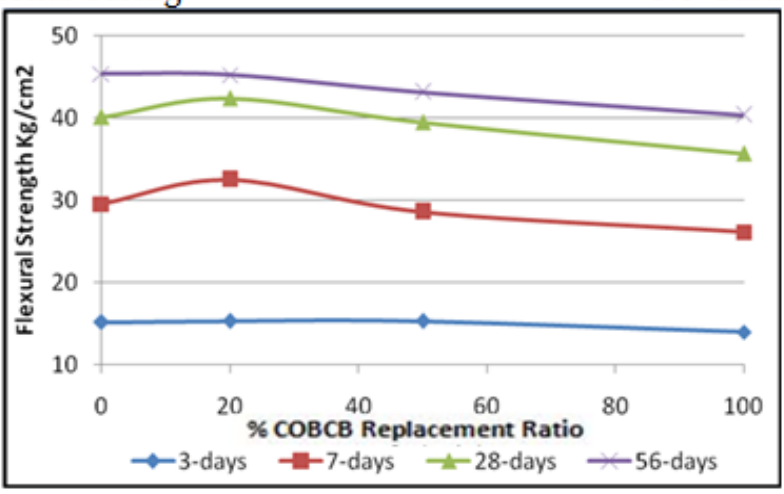

Chemical Curing

Fig. 6. Effect of \% (COBCB) on flexural strength. 
Yahia M. S. Abd El-Fattah et al., Improving of lightweight self-curing concrete properties

- The effect of curing type on the hardened concrete properties (Conventional curing (CC) as a reference):

A. Compressive Strength: Fig. (7) shows the compressive strength of all the concretes studied either without $\mathrm{COBCB}, 20 \%, 50 \%$ or $100 \%$ replacement ratio, which increase gradually with time in different rates. As usual conventional curing concrete gives higher compressive strength compared with the other curing. The compressive strength systematically decreased in case of no-curing larger than the chemical curing. At 28 days concrete without $\mathrm{COBCB}$, the reduction in the compressive strength was $8.1 \%$ for no-curing concrete and by about $4.7 \%$ for chemical cuing concrete when compared with conventional curing concrete. This reduction in the compressive strength disappears up to the replacement ratio was $50 \% \mathrm{COBCB}$, there is no significant difference between the different type of curing which may be because of the large amount of store water in the saturated COBCB particles. After the replacement ratio exceeded than 50\%, the reduction in the compressive strength appears again. At 28 days concrete with replacement ratio $100 \% \mathrm{COBCB}$, the reduction was $6.8 \%$ for self-curing concrete and by about $4.2 \%$ of chemical curing concrete when compared with conventional concrete.

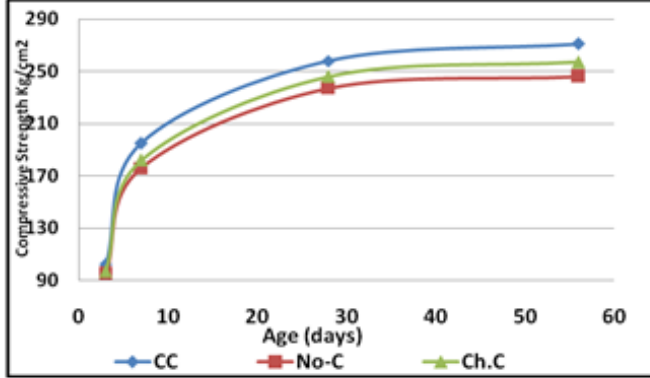

Concrete without $\mathrm{COBCB}$

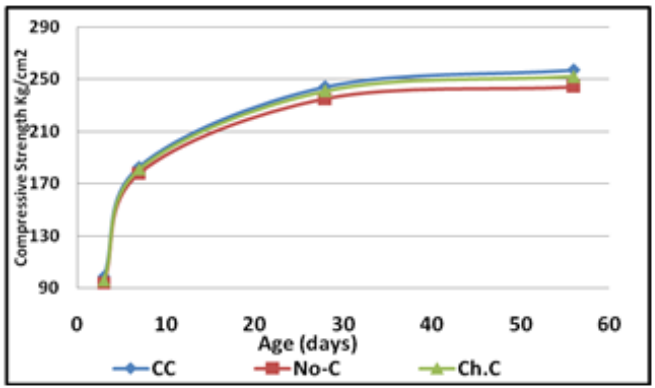

Concrete with $50 \%$ COBCB

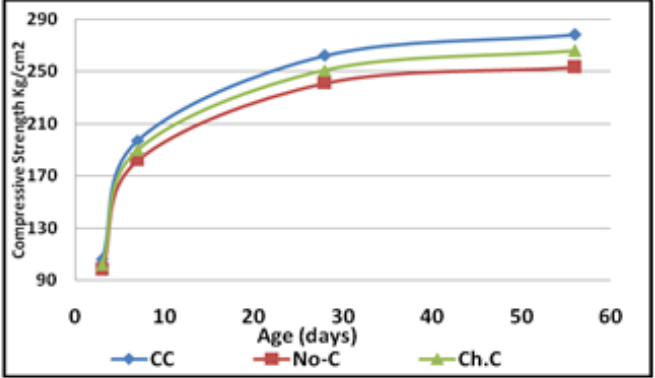

Concrete with $20 \%$ replacement

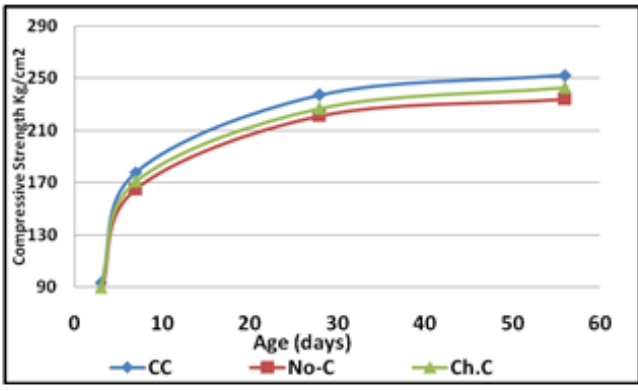

Concrete with $100 \%$ replacement

Fig. 7. Effect of curing type on compressive strength.

B. Indirect Tensile Strength: Fig. (8) shows the indirect tensile strength of all the concretes studied either without COBCB, $20 \%, 50 \%$ or $100 \%$ replacement ratio, which increase gradually with time in different rates. As usual conventional curing concrete gives higher indirect tensile strength compared with the other curing. The indirect tensile strength systematically decreased in case of no-curing larger than the chemical curing. At 28 days concrete without $\mathrm{COBCB}$, the reduction in the indirect tensile strength was $6 \%$ for no-curing concrete and by about $2.8 \%$ of chemical cuing concrete when compared with conventional curing concrete. This reduction in the 
JES, Assiut University, Faculty of Engineering, Vol. 44, No. 3, May 2016, pp. 259 - 271

indirect tensile strength disappears up to the replacement ratio was $50 \%$ COBCB, there is no significant difference between the different type of curing which may be because of the large amount of store water in the saturated COBCB particles. After the replacement ratio exceeded than $50 \%$, the reduction in the indirect tensile strength appears again. At 28 days concrete with replacement ratio 100\% COBCB, the reduction was $6.2 \%$ for self-curing concrete and by about $2.9 \%$ of chemical curing concrete when compared with conventional concrete.

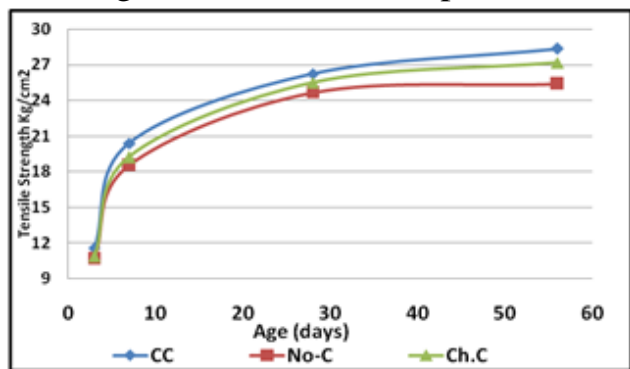

Concrete without $\mathrm{COBCB}$

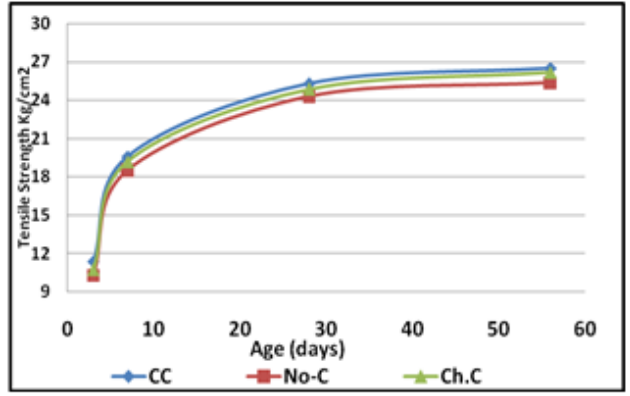

Concrete with $50 \%$ COBCB

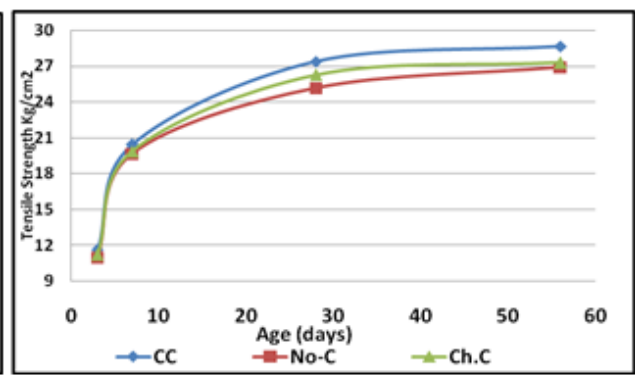

Concrete with $20 \%$ replacement

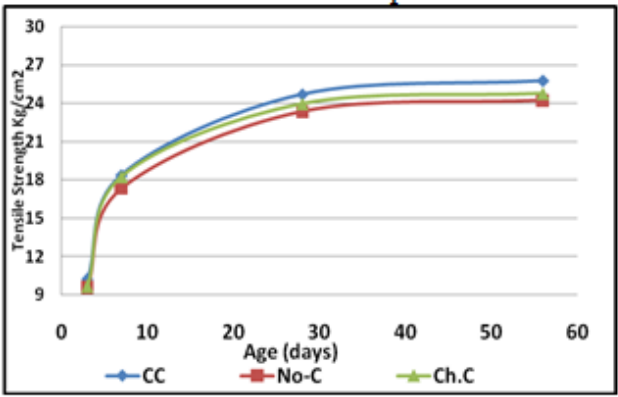

Concrete with $100 \%$ replacement

Fig. 8. Effect of curing type on indirect tensile strength.

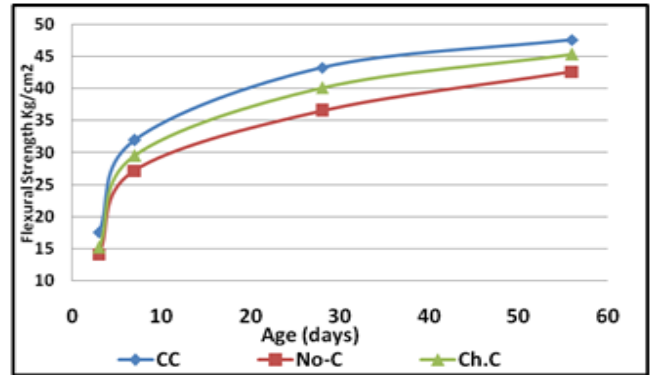

Concrete without $\mathrm{COBCB}$

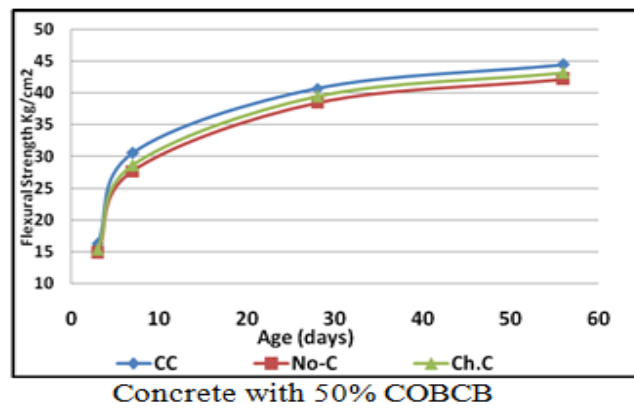

Fig. 9. Effect of curing type on flexural strength.

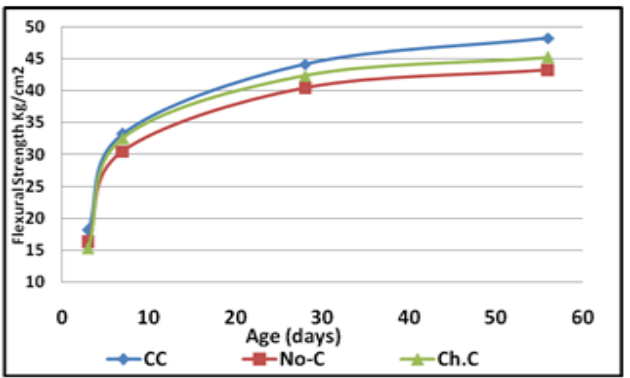

Concrete with $20 \%$ replacement

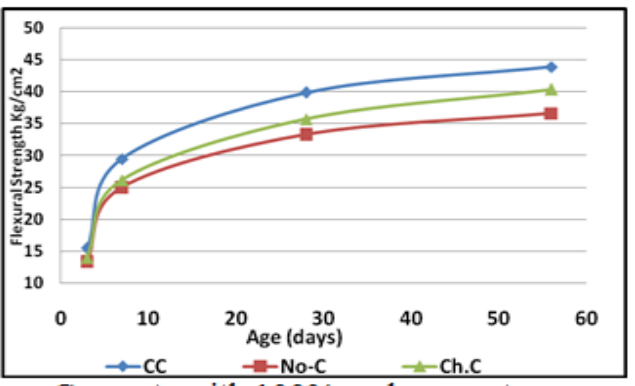

Concrete with $100 \%$ replacement 
Yahia M. S. Abd El-Fattah et al., Improving of lightweight self-curing concrete properties

C. Flexural Strength: Fig. (9) shows the flexural strength of all the concretes studied either without COBCB, $20 \%, 50 \%$ or $100 \%$ replacement ratio, which increase gradually with time in different rates. As usual conventional curing concrete gives higher flexural strength when compared with the other curing. the flexural strength systematically decreased in case of no-curing larger than the chemical curing. At 28 days concrete without $\mathrm{COBCB}$, the reduction in compressive strength was $15.5 \%$ for no-curing concrete and by about $9.1 \%$ of chemical cuing concrete when compared with conventional curing concrete. This reduction in the flexural strength disappears up to the replacement ratio was $50 \% \mathrm{COBCB}$, there is no significant difference between the different type of curing which may be because of the large amount of store water in the saturated $\mathrm{COBCB}$ particles. After the replacement ratio exceeded than 50\%, the reduction in the flexural strength appears again. At 28 days concrete with replacement ratio $100 \% \mathrm{COBCB}$, the reduction was $16.6 \%$ for self-curing concrete and by about $10.5 \%$ of chemical curing concrete when compared with conventional concrete.

\section{Conclusion}

Based on the results it has been concluded that,

- The unit weight of lightweight concrete produced with crushed COBCB decreased gradually with the increasing of $\%$ replacement ratio. When the \% replacement ratio is $100 \%$, the reduction of unit weight is $23 \%$ when compared with the control one. By using lightweight structural concrete with $\mathrm{COBCB}$, the dead load and as a result the weight of the building will be considerably decreased. So it is possible to reduce the dimensions of the supporting structure, minimize the earthquake force on the building and economize the project.

- In contrast to this decrease in unit weight, there is a decrease in the compressive strength of $\mathrm{COBCB}$ concrete of $8 \%$.

- The use of self-curing agents $\mathrm{COBCB}$ in concrete mixes enhances the mechanical properties. The value of $20 \%$ saturated $\mathrm{COBCB}$ represent the optimum doses as selfcuring agents in concrete for all of curing type.

- The increasing of compressive strength of internally cured mixtures with $20 \%$ COBCB replacement ratio is $1.7 \%$ for conventional curing and no-curing and $2 \%$ for chemical curing when compared with control mixtures without COBCB.

- The increasing of indirect tensile strength of internally cured mixtures with $20 \% \mathrm{COBCB}$ replacement ratio is $4.3 \%$ for conventional curing concrete, $2.1 \%$ for self-curing concrete and $3 \%$ for chemical curing concrete when compared with control mixtures without COBCB.

- The increasing of flexural strength of internally cured mixtures with 20\% COBCB replacement ratio is $5 \%$ for all cases of curing when compared with control mixtures without COBCB.

- It is clear that, when the replacement ratio is $50 \% \mathrm{COBCB}$, there is no significant difference between the different type of curing which may be because of the large amount of store water in the saturated COBCB particles.

\section{REFERENCES}

[1] Holm, T. A., "Performance of Structural Light-weight Concrete in a Marine Environment", American Concrete Instiute, Farmington Hills, Mich., 1980, pp.589-608.

[2] Khokrin, N. K. "The durability of lightweight concrete structural members," Kuibyshev, USSR (in Russian), 1973. 
[3] Hoff. G.C., "Internal Curing of Concrete Using Lightweight Aggregates", American Concrete Instiute, Volume 234, March 2006, P621-640.

[4] ArnonBentura, Shin-ichiIgarashib, Konstantin Kovlera, "Prevention of autogenous shrinkage in high-strength concrete by internal curing using wet lightweight aggregates", Cement and Concrete Research, Volume 31, Issue 11, November 2001, Pages 1587-91.

[5] Ryan Henkensiefken, Javier Castro, Haejin Kim, Dale Bentz, and Jason Weiss "Internal Curing Improves Concrete Performance throughout its Life" Concrete In Focus, September-October 2009.

[6] J. Schlitter, et al. "Development Of Internally Cured Concrete For Increased Service Life." FHWA/IN/JTRP-2010/10, SPR-3211.

[7] Dayalan J, B. M. "Internal Curing of Concrete Using Prewetted Light Weight Aggregates." International Journal of Innovative Research in Science, Engineering and Technology, 2014, 3(3): 7.

[8] Magda I. Mousa, et al. "Mechanical properties of self-curing concrete (SCUC)." HBRC Journal 2014.

[9] Egyptian Code for Design and Construction of R.C. structures, 2006. 


\section{تحسين خواص الخرسانة خفيفة الوزن والمعالجة ذاتيا}

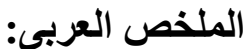

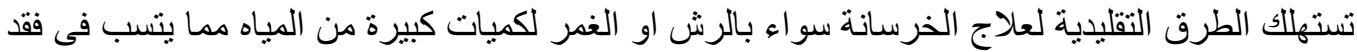

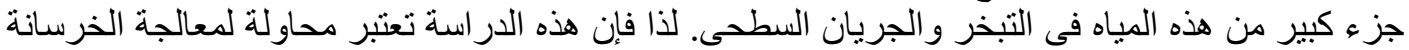

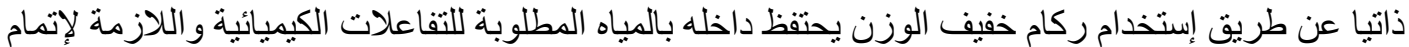

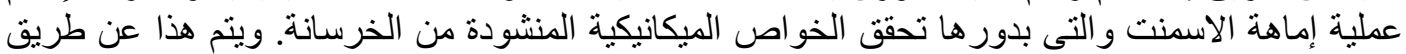

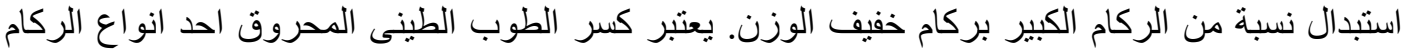

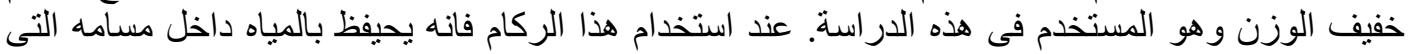

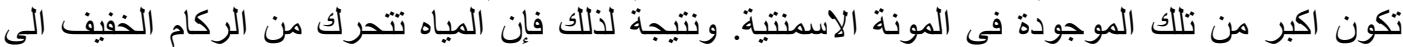

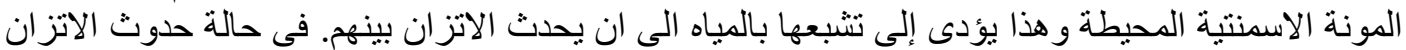

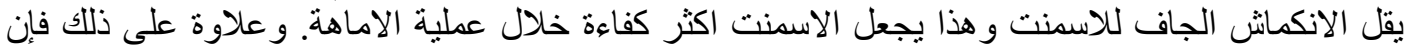

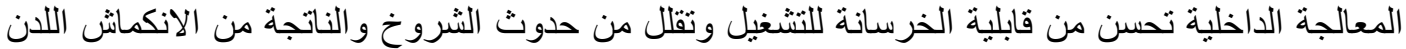
و الجاف. ونتيجة لكل ما سبق فهذا يزيد من قوة التماسك بين الركام الخفيف و المونة الاسمنتية الذى يؤدى الأكياك اللى تقليل نفاذية الخرسانة.

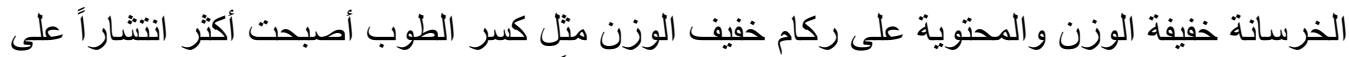

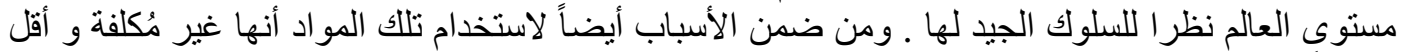
ضرر أ للبيئة مقارنة بالمو اد الاخرى.

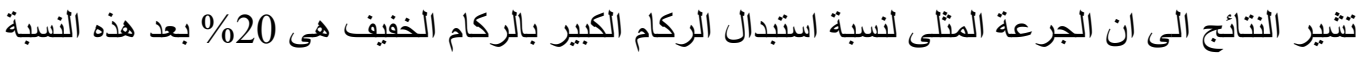

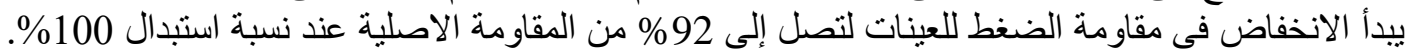

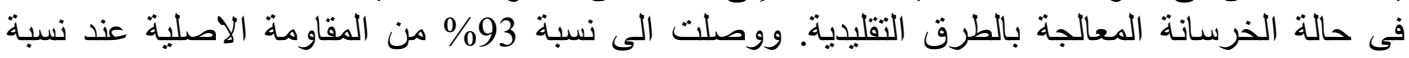

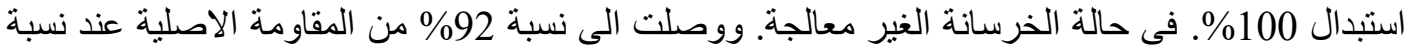
استبدال 100\%. فى حالة الخرسانة المعالجة بالمادة الكيميائية. 